\title{
原著
}

\section{脳損傷者における感情表出の損傷半球別検討 一表情分析と心理・行動特徵の関連性一}

\author{
小 浜 尚 也 ${ }^{*} * *$ 種 村 純 $* * *$
}

要旨 : 右半球損傷者 38 例, 左半球損傷者 34 例, 両側半球損傷者 12 例を対象に損傷半球別の表情の特徵 と質問紙評価・行動評価との関連性を検討した。表情の評価に Facial Expression Coding System(FACES), 意欲と精神状態の評価に Apathy Evaluation Scale 介護者評価の日本語版 (AES-I-J), 標準意欲評価法 （CAS）の日常生活行動の意欲評価スケール，Neuropsychiatric Inventory（NPI）を用いた。右半球損傷者 は他の半球損傷例に比し有意に意欲・発動性の低下を示した。FACESの各表情と AES-I-J, CAS, NPI の関連性を検討した。FACES の悲しみ表情と NPIのうつ, FACES の幸福表情と NPI の多幸, FACES の 無関心表情と AES-I-J の総得点, CAS の総得点, NPI の無関心の各項目で 0.7 以上の高い正の相関関係 が認められた。FACESにより右半球損傷者には驚き，幸福，無関心の表情，左半球損傷者には悲しみの 表情が多くみられ, 両側半球損傷者は特徵的な表情を示さなかった。右半球損傷者はポジティブおよび中 立な感情価，左半球損傷者はネガティブな感情価の表情を呈することを示唆した。

(高次脳機能研究 39 (2)：229～236，2019）

Key Words : アパシー, 無関心, 右半球, 表情分析, 情動 apathy, indifference, right hemisphere, Facial Expression Coding System, emotion

はじめに

Borodら（2001）は 1987 年から 1998 年の 12 年 間にわたる表情研究の文献を調查し, 右半球が表情 の認知を担っていることを示した。さらにPET, fMRI 用いた研究の調査から, 右半球後部皮質が 感情情報の認知に特化した部分であることも示し た。一方, 表情出現に関しては, 健常成人を対象と した研究において右半球との関与を見出し, さらに この結果は多くの右半球損傷患者の症例報告と一致 するとした。しかしながら, 脳損傷群の集団研究が 少ないこと, 表情認知の分野と比べ報告数が限られ ていることが問題点として挙げられている（Borod ら 2001)。

表情の評価において代表的なものは顔面運動の観 察的評価である。この領域で最も影響力のある分析 法は, Ekman ら（1978）が開発した Facial Action Coding System (FACS) である。FACS は,"AU (Action Unit)”と呼ばれるもので,「解剖学的に独立し, 視 覚的に識別可能な表情動作の最小単位」を組み合わ
せて表情を定量的に記述する。表情の動きを変換 ルールに従い 44 種の AUにし, それを組み合わせ ることによって，人間のあらゆる表情が記述可能と されている。しかし，細かな顔面筋運動の測定によ り分析作業が膨大となるため, 対象者の表情動作の 長い時間のうち一部しか評価できていないことが多 く, 評価者の主観的な表情評価と比べ自然な表情変 化の評価として適切でない可能性が指摘されている (Buck 1990, Blonder ら 1993, Kring ら 2007)。

Kring ら（2007）は, Ekman ら（1978）が開発し た FACS の感情次元モデルに基づき, Facial Expression Coding System（FACES）を開発した。FACES はFACSよりも，さらに自然な表情変化の評価を可 能とし，また，FACSの細かな評価をより簡易にす ることを目的としている。FACES は現在に至るま で多くの研究で信頼性が検証されている（Kring ら 1994，2003)。さらに, FACES と FACS は異なる 2 つのシステムであるが, 同様の結果を得ることが可 能であった（Kring ら 2007）。

本研究では, FACES を用いて脳損傷後の損傷半球 
別の特徴的な表情を明らかにすることを目的とした。

\section{I. 対 象}

倉敷紀念病院において, 2014 年度と 2015 年度の 2 年間に脳損傷により回復期リハビリテーション病 棟に入院し, 言語聴覚療法を実施した者を対象とし た。意識障害例, 病前にうつなどの精神疾患があっ た者，下記の方法に述べる評価が実施不可能な者を 除外し, その結果, 右半球損傷者 (right hemisphere damage：RHD） 38 例, 左半球損傷者 (left hemisphere damage : LHD） 34 例, 両側半球損傷者（bilateral hemisphere damage：BHD） 12 例, 合計 84 例が対象となった。

\section{II. 方 法}

\section{1. 表情の評価}

表情の評価は Kring ら（2007）が開発した FACES を用いて行った。FACESは対象者の表情から，表 情出現の頻度, 強度, 怒り・悲しみなどの感情的な 価, 持続時間を評価する。評価は表情の変化が起き るとき，表情が出現してから顔面が中立の表情（無 表情）に戻るか，異なる表情に変化すると，その表 情を 1 回の表情出現とカウントする。次に, 検出さ れた感情価の強度を 1 (低い) から 4 (非常に高い) の 4 段階のリッカート尺度を用い評価する。そして 表情出現の持続時間を測る。表情出現が検出されれ ば計時を開始し，顔面が中立の表情（無表情）に戻 るか, 異なる表情に変化したときに, 計時を終える。 最後に表情の総合評価として, 強制選択評価票を用 いた評価を行う。この評価票では，上記の結果をも とに対象者が全体を通じて表出した優性な感情を評 価する。対象者が示した表情を，関心，悲しみ，怒 り，驚き，嫌悪，無関心，幸福の 7 つに分け，5段 階のレベル（低い, 少し低い, 中間, 少し高い, 高 い）で各感情価（1～5 点）を評価する。低いレベ ルの評価は, その表情出現が示されず,またはほとん どの表情の出現時間が短く強度も低かった対象者に 与えられる。高いレベルの評価は, 多くの場合でそ の表情を示し, 高い強度で表情出現時間も長かった 対象者に与えられる。また, FACS P FACES のよ うな表情の評価は与えられた映像のみで評価し, 主 観的要素を一切排除して行うものである。

1) 評価の概要

評価は認定 FACS コーダーである筆頭著者を含め
対象者を担当した言語聴覚士 4 名で行った。各評価 者が対象者の動画を見て表情を評価した。対象者の 顔は, 本人の同意を得たうえで写真や動画で撮影し, 評価対象データとして用いた。対象者には意図的に 表情を表出するような教示は与えず，普段の様子を 記録するために撮影すると説明した。対象者の写真 は表情分析の基準（基本顔）として使用することと し, 動画は食事場面, 余暇活動や会話場面など日常 生活の場面を撮影した。動画の音声はなく,評価者は 対象者の顔面動作のみを観察・評価し，各評価者が 最終的に判断した強制選択評価票の結果を本研究の 分析対象とした。

2) 装置

SONY 社製デジタルビデオカメラレコーダー HDRPJ630V を使用し撮影した。動画編集のために NEC 社製パーソナルコンピュータ HA850BASを使用し た。対象者の顔の撮影は, 対象者の正面にカメラを 設置し, 顔をフレームの中心で捉え上半身から顔が 映るようにした。動画は 32 インチのモニターに映 し出し, 各評価者が動画を見て評価をした。評価を する際のモニターから評価者までの距離は $150 \mathrm{~cm}$ に設定した。評価のため, 動画は各評価者が繰り返 し再生できるようにした。

\section{3）手続き}

評価者全員に事前に評価票を配布し，本研究者が 口頭で評価の方法と表情の特徵を説明するオリエン テーションを実施した。対象者の表情を FACES の 評価票に基づき採点した。ベース写真をもとに，変 化した顔面動作を動画にて評価した。評価者は，各 表情の参考画像（Ekman ら 1987）を参照しながら 評価用の記入を行った。参考画像の参照は評価用紙 に記入する際, 各自が随時参照した。表情出現の頻 度, 強度, 感情価, 持続時間について評価を行った 後, 最後に強制選択評価票により各対象者が示した 優性の表情を評価した。評価者に対して参考画像が どの表情であるか, どの表情がどのような特徵を持 つかの説明は最初のオリエンテーションで行った。 最初のオリエンテーション後に 4 人並んで評価を行 い，以降は評価者がそれぞれ動画を見て各自で評価 を行った。

\section{2. 意欲と精神状態の評価}

意欲の評価には Apathy Evaluation Scale 介護者 評価の日本語版（AES-I-J, 葛西ら 2014）を用いた。 AES-I-J では各質問に対し,まったくあてはまらない, 
わずかにあてはまる, 多少あてはまる，とてもよく あてはまる，の 4 件法（1～ 4 点）で評価する。総 合点は全 18 項目で 72 点満点であり, 点数が高いほ ど意欲低下が重度であることを示している。行動観 察的評価として, 標準意欲評価法 (CAS) の日常生活 行動の意欲評価スケールを用いた（加藤ら 2006）。 このスケールにおいて, 評価者は, 対象者の意欲を日 常生活の行動項目別に観察して評価する。評価され る行動項目は 16 項目で, 5 段階評価（0〜 点）で ある。総合計点は全 16 項目で 64 点満点であり, 点 数が高いほど日常生活での意欲低下が重度であるこ とを示している。行動および心理症状の評価として Neuropsychiatric Inventory (NPI) の日本語版 (博 野ら 1997）を用いた。NPIは妄想, 幻覚, 興奮, う つ, 不安, 多幸, 無関心, 脱抑制, 易刺激性, 異常 行動についてあり・なしで回答し, それぞれの頻度 を 1 〜の 4 段階で, 重症度を 1 〜 の 3 段階で評 価する。各項目のスコアは頻度 $\times$ 重症度の最大 12 点で表され, 点数が高いほど症状が重度であること を示している。評価は対象者を担当した言語聴覚士 4 名で行った。

\section{3. 統計解析}

統計学的解析は IBM SPSS Statistics version 21 (IBM Corp., Armonk, New York, USA) を用いて, 各評価の損傷半球別に得点の差を検定した。検定は Kruskal-Wallis 検定を適用し, 主効果が有意であっ た項目に多重比較法を用いた。FACESによる感情 障害の評価の妥当性を検討するために, FACES と AES-I-J, CAS, NPI との相関関係を Spearmanの 順位相関係数を用いて分析した。いずれの検定も有 意水準は $5 \%$ 未満とした。

\section{4. 倫理的配慮}

本研究は倉敷紀念病院の倫理委員会にて承認を得た。

\section{III. 結 果}

\section{1. 各評価の損傷半球別の平均得点}

FACES の各表情の平均得点はその種類により得 点が大きく異なった（図 1)。Kruskal-Wallis 検定 を適用すると,「悲しみ」,「驚き」,「無関心」,「幸福」 で損傷半球別の得点差が有意であることが確認され た。多重比較法を行った結果, RHD群においては「驚 き」,「無関心」,「幸福」の項目の得点が LHD 群に比 し有意に高かった。LHD 群においては「悲しみ」の 項目がRHD 群に比し有意に高かった。BHD 群は
他の群に比して高い得点の表情はなかった（表 1)。 動画の時間は短いもので 30 秒, 長いもので 5 分で あり, 各表情の出現時間は約 1 秒から 10 秒であった。

AES-I-J 各項目の平均得点はすべての項目におい て RHD 群, BHD 群の順に得点が高く, LHD 群の 得点が低かった（図 2)。Kruskal-Wallis 検定を適 用し, すべての項目で損傷半球別の得点差が有意で あることが確認された。多重比較法の結果, RHD 群の得点が LHD 群に比し, すべての項目において 有意水準 $1 \%$ で高かった。

CAS 各項目の平均得点はすべての項目において RHD 群, BHD 群の順に得点が高く, LHD 群の得 点が低かった（図 3)。Kruskal-Wallis 検定を適用 すると, 項目 $12\lceil$ 電話をする」以外の項目で損傷 半球別の得点差が有意であることが確認された。そ して, 項目 12 電話をする」を除いた項目に多重 比較法の結果, すべての項目で RHD 群が LHD 群 に比し有意に高い得点を示した。

NPI の各項目平均得点は項目により大きく相違し た（図 4)。Kruskal-Wallis 検定を適用すると，「幻

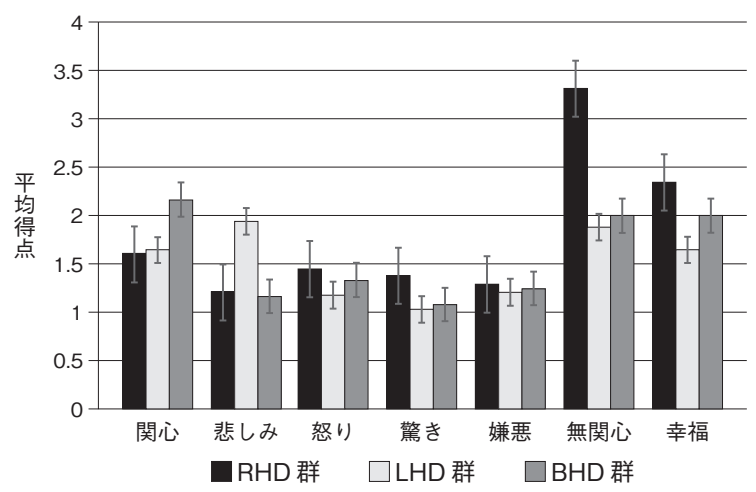

図 1 FACES による各表情の損傷半球別の平均得点 error bar は標準誤差を示している。

表 1 FACES による各表情の損傷半球間の得点の差の検定 (数字は $\mathrm{p}$ 值)

\begin{tabular}{cccc}
\hline & RHD-LHD & RHD-BHD & LHD-BHD \\
\hline \hline 関心 & - & - & - \\
\hline 悲しみ & $0.036^{*}$ & 1 & 0.091 \\
\hline 怒り & - & - & - \\
\hline 驚き & $<0.01^{* *}$ & 0.217 & 1 \\
\hline 嫌悪 & - & - & - \\
\hline 無関心 & $<0.01^{* *}$ & $0.023^{*}$ & 1 \\
\hline 幸福 & $0.024^{*}$ & 1 & 1 \\
\hline${ }^{*}<<.05,{ }^{* *}{ }_{p}<.01$ & &
\end{tabular}




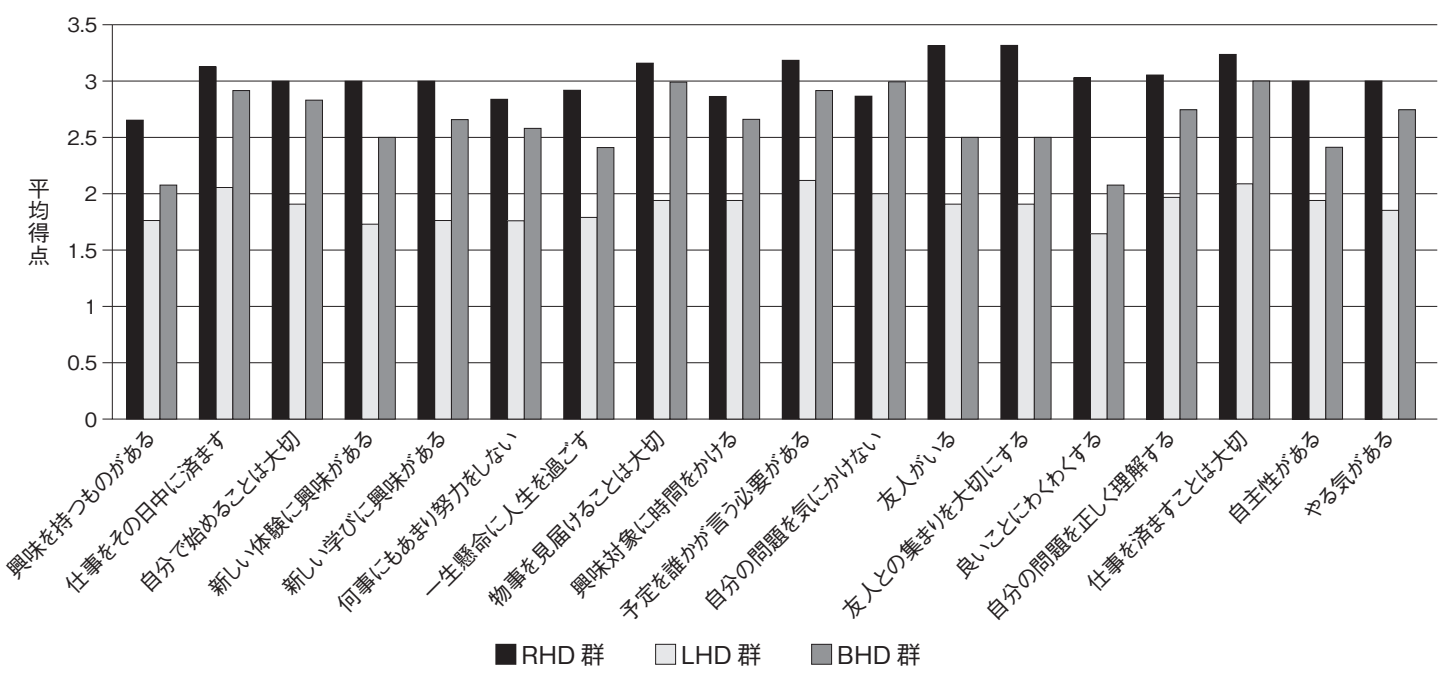

图 2 AES-I-Jによる意欲の損傷半球別の平均得点

右半球損傷者の得点が左半球損傷者に比しすべての項目において有意水準 $1 \%$

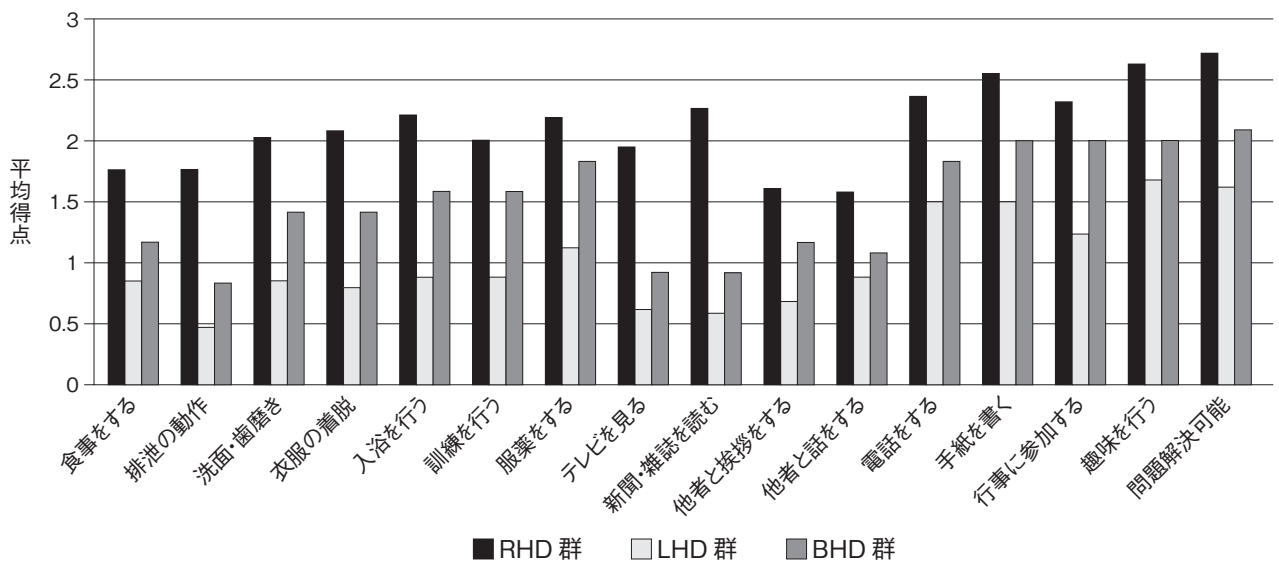

図 3 CASによる日常生活の意欲の損傷半球別の平均得点

「電話をする」以外の項目で右半球損傷者の得点が左半球損傷者に比し有意に高かった。

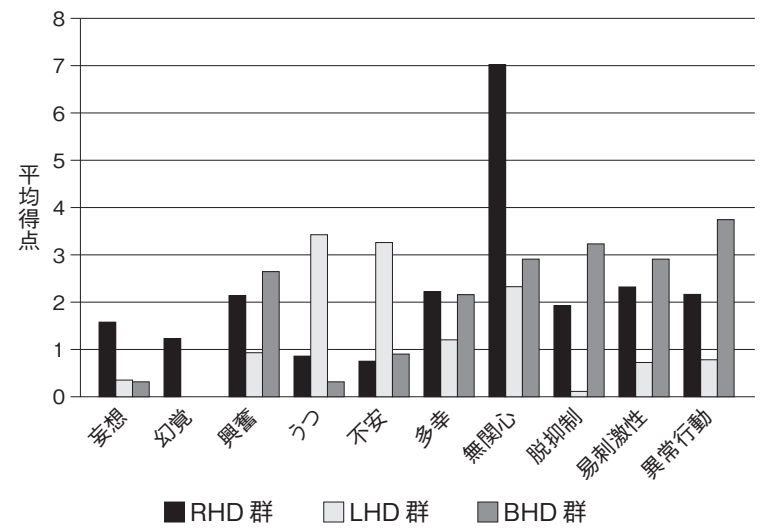

図4ＮPIによる行動および心理症状の損傷半球別の平均得点
覚」,「うつ」,「不安」,「無関心」,「脱抑制」の項目 で損傷半球別の得点差が有意であることが確認され た。多重比較法の結果, RHD 群においては,「幻覚」, 「無関心」の項目の得点がLHD 群に比し有意に高 かった。LHD 群においては,「うつ」,「不安」の項 目の得点がRHD 群に比し有意に高かった。BHD 群においては,「脱抑制」の項目の得点が LHD 群 に比し有意に高かった（表 2）。

\section{FACES の各表情と各評価法間の相関関係}

FACES の各表情と AES-I-J, CAS, NPI の関連 性を求めた。「関心」,「怒り」,「驚き」,「嫌悪」の各 表情では 0.7 以上の高い相関を示す項目はなかった。 
表 2 NPIによる行動および心理症状の損傷半球間の得点の 差の検定（数字は $\mathrm{p}$ 值）

\begin{tabular}{cccc}
\hline & RHD-LHD & RHD-BHD & LHD-BHD \\
\hline \hline 妄想 & - & - & - \\
\hline 幻覚 & $0.015^{*}$ & 0.137 & 1 \\
\hline 興奮 & - & - & - \\
\hline うつ & $<0.01^{* *}$ & 1 & 0.022 \\
\hline 不安 & $0.019^{*}$ & 1 & 0.197 \\
\hline 多幸 & - & - & - \\
\hline 無関心 & $<0.01^{* *}$ & 0.037 & 1 \\
\hline 脱抑制 & 0.058 & 0.523 & $<0.01^{* *}$ \\
\hline 易刺激性 & - & - & - \\
\hline 異常行動 & - & - & - \\
\hline * $<.05,{ }^{* *} \mathrm{p}<.01$ & &
\end{tabular}

「悲しみ」の表情と NPI の「うつ」,「無関心」の表情 と AES-I-J「総得点」, CAS「総得点」, NPI「無関心」 の各項目,「幸福」の表情と NPI「多幸」の項目で 0.7 以上の高い正の相関関係を示した。

\section{IV. 考察}

\section{1. 損傷半球別の特徵的な表情}

FACES を用いて損傷半球別の特徵的な表情につ いて検討した。RHD 群は他の半球損傷群に比し多 くの患者が「無関心表情」, LHD 群に比し「驚き表 情」,「幸福表情」を呈し, LHD 群はRHD 群に比し多 くの患者が「悲しみ表情」を呈した。BHD 群では他 の損傷半球群に比し有意に高い得点を示す表情はな かった。BHD 群が特徵的な表情を示さなかったの は, 損傷領域が広範な BHD 群は意識障害が重度と なり本研究の対象者から除外され, 脳損傷領域が広 範でない患者が対象となっているためと考えられる。

FACESにおいて「驚き表情」と「幸福表情」の感 情価はポジティブな価,「悲しみ表情」はネガティ ブな価に位置づけられる。「無関心表情」はポジティ ブ，ネガティブのいずれでもなく，表情変化のない 中立の表情とされる。この結果から, RHD 群はポ ジティブな感情価の表情または中立な感情価の「無 関心表情」を多く呈しており，LHD 群はネガティ ブな感情価の表情を多く呈していた。Davidson ら （1979）は, 大脳半球別の感情価についてポジティ ブの感情の左半球，ネガティブの感情の右半球優位 の神経心理学モデルを仮定し，この理論により多く の臨床および実験データを説明できると主張した。 しかし, その後の研究で多くは Davidson ら（1979） の感情価仮説を支持する結果が得られておらず
(Gainotti 2001), RHD がネガティブ, LHD がポジ ティブな感情価の表情表出の障害を呈していると単 純に分けることは不適切である。特に, 感情価仮説 では RHD が中立な感情価の「無関心表情」を多く 呈した本研究の結果を説明するのに不十分である。 また, 表情の生成において右半球が左顔面, 左半球 が右顔面の機能を担っていると仮定し様々な研究が なされた。健常成人を対象により強い表情が左顔面 で頻繁に起こることが確認されるが (Ekman ら 1981)，ポジティブ感情・ネガティブ感情に関連す る表情は左右顔面で一貫性は認められなかった (Hagerら 1985)。このような背景から Gainotti （2001）は, 表情の表出は右半球が優位な機能を担っ ているとしつつも, Davidson ら（1979）の感情価仮 説では各損傷半球の臨床的特徵を説明できないとし, 新たな説を提唱した。Gainotti（2001）は右半球と 左半球がそれぞれ担う感情のレベルが異なることを 指摘し，これにより RHD の無関心反応と LHD の 破局反応の説明を試みている。右半球は自動的レベ ルの感情を担うとし, 環境刺激によって条件づけら れ，学習に基づいた所定の自動的運動プログラムお よび感情が形成されるとした。左半球は制御的レベ ルの感情を担うとし, 刺激に対し意味記憶に基づい て認知的評価を行い，社会的ルールに応じた制御的 で意図的な感情表現を形成するとした。これにより RHD は自動的レベルの感情機能が障害され, 感情 的刺激に対し選択的で自動的な反応を生成できない ために「無関心反応」を生じるとし，LHD は制御 的レベルの感情機能の障害により, 感情的刺激に晒 されたときに感情の制御ができず過剩な反応として 「破局反応」を生じるとした。本研究で得られた結 果をこの理論に基づいて整理すると，RHDの「無 関心表情」は右半球の担う自動的レベルの感情機能 の障害により，選択的で自動的な感情反応ができず 「無関心表情」として表れ，LHDの「悲しみ表情」 は左半球の担う制御的レベルの感情機能の障害によ り，悲しみ感情が制御できず「悲しみ表情」を多く 呈したと考えられる。LHD が他の半球損傷群より も多く悲しみ感情を呈していたことはNPIの結果で 「うつ」,「不安」の得点が高いことから示されてい るが, NPI の他の項目でLHD が高い得点を示した 項目はない。この結果から, LHD は「脳損傷によ る入院や身体機能の低下」というストレス場面にさ らされることにより, 悲しみ感情を抱き「悲しみ表 
情」が制御できず出現したが，他の感情のストレス 場面には晒されていないので，他の表情が出現しな かったと考えられるが, 本研究では本人の意識につ いての調査がなされておらず，今後さらなる検討が 必要である。

本研究で RHD が最も多く呈した表情は「無関心 表情」であるが，ポジティブ感情に位置づけられる 「驚き表情」や「幸福表情」をLHDよりも有意に多 く呈した。RHDの多幸性について古くは Babinski （1914）が報告し, その後も多くの研究者が同様の観 察を報告している（Hecaen ら 1951，Denny-Brown ら 1952)。多くの研究者が臨床的観察で RHD の多 幸性を報告したように，本研究においても RHD は LHD よりも NPI「多幸」の得点が高い。このことから， RHD はLHD よりも感情的にポジティブな多幸状 態にあるためにポジティブな感情価である「驚き表 情」や「幸福表情」を呈したと考えられる。RHD 群 において多く呈したポジティブな感情価の表情が, 残された左半球により制御されなかったのは，ネガ ティブ感情は社会生活上制御される対象となるが, ポジティブ感情は制御の対象となりにくいため (Etcoff 1986), RHD は残された左半球の制御を受け ずポジティブな感情価の表情を多く呈したと思われ る。本研究により RHD が LHD よりもポジティブ な感情価の表情を多く呈することが示されたが, 感 情状態に関連する本人の意識についての情報が得ら れておらず,ささらなる検討が必要である。

\section{2. 質問紙評価，行動評価と FACES を用いた表 情評価の関連性}

Spearman の順位相関係数を用いて FACES の各 表情と意欲評価の AES-I-J, 日常生活の意欲評価の CAS，行動および心理症状評価の NPI の関連性を 検討した。その結果,「悲しみ表情」と抑うつの評価, 「無関心表情」と意欲障害の評価,「幸福表情」と多 幸性の評価が関連することが示された。FACESを 用いた研究で, 感情的刺激に対する感情の内省報告 と表情出現の関連性を検討した研究があるが (Kring ら 1994), 対象者は健常成人であった。健 常成人を対象に表情出現の研究がいくつかなされて いるが (Borodら 1990, Mandalら 1992), 表情分 析を用いた脳損傷者の表情出現の研究は少ない。今 回我々が得た結果により, 質問紙・行動評価に対し て FACES を用いた表情評価法も脳損傷者の感情障 害の検出のうえで妥当性があることを示唆した。

\section{3. 脳損傷者における表情評価について}

多くの研究が RHD の表情出現の障害を示してい る（Buck ら 1980, Borodら 1985）。これらの報告 とは対照的に Mammucari ら（1988）はFACSを用 い LHD, RHD, 正常群の 3 群に感情を喚起する映 像を見せ表情を分析し，3 群間の表情出現に有意な 差が認められないと述べた。この報告に対し Buck (1990), Blonder ら (1993) は, Mammucari ら (1988) の報告が FACS 評価により不必要な顔面筋運動の評 価が加わり自然な表情が評価できていないこと，実 験室内での評価であること，RHD が視空間および 注意障害により視覚刺激に反応していない可能性が あることを指摘し，評価者が主観的に評価している 報告（Buckら 1980, Borodら 1985）とは比較で きないとした。

Blonder ら（1993）は脳損傷者の自発的表情の評 価を目的に，家族との会話時の表情を各対象者の自 宅で評価し, RHD 群が LHD 群および正常群と比 較して表情出現が有意に低下していることを示し た。Blonderら（1993）の報告は, より自然な自発 的表情の評価を目的としているため, FACS 評価で はなく評価者による主観的評価を用いたが, 評価者 の表情分析の知識については記載されておらず, 評 価の妥当性が保証されているとは言い難い。

本研究は脳損傷者が普段示す表情を撮影し, 各損 傷半球別の特徵的表情を示した。表情の評価は FACS 評価と同様に客観的評価が可能であり，自然 な表情変化の評価を目的に開発された FACES の評 価手続きに基づいて行った。本邦において FACES を用いて脳損傷者の表情を評価した報告はない。ま た，本邦において FACS を用いた健常成人の表情評 価の報告はあるが（Nomura ら 2011），損傷半球別 検討は行われておらず，本研究のような認定 FACS コーダーによる脳損傷者の表情評価を行った報告も 見当たらない。

\section{V. 結 論}

本研究により, 損傷半球別の特徵的な表情を見出 すことができた。LHD が抑うつ症状，RHD がアパ シー症状をより多く呈するという従来の報告と関連 づけられる結果を表情分析においても得ることがで きた。また，損傷半球別の表情の特徴と質問紙・行 動評価との関連性が示されたことにより，脳損傷後 の情動評価に表情分析の有効性が示された。 
謝辞 : 本稿作成にあたりご協力いただきました，医 療法人誠和会倉敷紀念病院リハビリテーション科に 深謝致します。

\section{文献}

1 ) Babinski, M. J. : Contribution a l'etude des troubles mentaux dans l'hemiplegie organique cerebrale (anosognosie). Rev. Neurol., $27: 845-847,1914$.

2 ) Blonder, L. X., Burns, A. F., Bowers, D., et al. : Right hemisphere facial expressivity during natural conversation. Brain Cogn., 21 : 44-56, 1993.

3 ) Borod, J. C., Koff, E., Lorch, M. P., et al. : Channels of emotional expression in patients with unilateral brain damage. Arch. Neurol., 42 : 345-348, 1985.

4 ) Borod, J. C., St. Clair, J., Koff, E., et al. : Perceiver and poser asymmetries in processing facial emotion. Brain Cogn., 13 : 167-177, 1990.

5 ) Borod, J. C., Zgaljardic, D., Tabert, M. H., et al. : Asymmetries of emotional perception and expression in normal adults. In : Emotional behavior and its disorders ; handbook of neuropsychology (ed Gainotti, G.) . 2th Ed., Elsevier, Amsterdam, 2001, pp. 181-205.

6 ) Buck, R. \& Duffy, R. J. : Nonverbal communication of affect in brain-damaged patients. Cortex, $16: 351-362$, 1980.

7 ) Buck, R. : Using FACS vs. communication scores to measure spontaneous facial expression of emotion in braindamaged patients ; a reply to Mammucari et al. (1988). Cortex, $26:$ 275-280, 1990.

8 ) Davidson, R. J., Schwartz, G. E., Saron, C., et al. : Frontal versus parietal EEG asymmetry during positive and negative affect. Psychophysiology, 16 : 202-203, 1979.

9 ) Denny-Brown, D., Meyer, J. S. \& Horenstein, S. : The significance of perceptual rivalry resulting from parietal lesion. Brain, 75 : 433-471, 1952.

10) Ekman, P. \& Friesen, W. V. : The facial action coding system ; manual. Consulting Psychological Press, Palo Alto, California, 1978.

11) Ekman, P., Hager, J. C. \& Friesen, W. V. : The symmetry of emotional and deliberate facial actions. Psychophysiology, 18 : 101-106, 1981.

12）Ekman, P. \& Friesen, W. V. : 表情分析入門 ; 表情に隠さ れた意味をさぐる (工藤 力, 訳編)。誠信書房, 東京, 1987.

13) Etcoff, N. : The neuropsychology of emotional expres- sion. In : Advances in clinical neuropsychology (eds Goldstein, G. \& Tarter, R. E.). Plenum Press, New York, 1986, pp. 127-179

14) Gainotti, G. : Components and levels of emotion disrupted in patients with unilateral brain damage. In : Emotional behavior and its disorders. Handbook of Neuropsychology (ed Gainotti, G.). 2th Ed., Elsevier, Amsterdam, 2001, pp. 161-179.

15) Hager, J. C. \& Ekman, P. : The asymmetry of facial actions is inconsistent with models of hemispheric specialization. Psychophysiology, 22 : 307-318, 1985.

16）博野信次, 森 悦朗, 池尻義隆, ほか：日本語版 Neuropsychiatric Inventory; 痴呆の精神症状評価法の有用 性の検討. Brain and Nerve, 49 : 266-271, 1997.

17) Hecaen, H., De Ajuriaguerra, J. \& Massonnet, J. : Les troubles visuo-constructifs par lésion pariéto-occipitale droite ; role des perturbations vestibulaires. L'encéphale, $40: 122-179,1951$.

18）葛西真理, 目黒謙一, 中村 馨: Apathy Evaluation Scale 介護者評価の日本版 (AES-I-J) 作成. 日本老年医学会 杂隹誌, 51 : 445-452, 2014.

19）加藤元一朗, 注意 - 意欲評価法作製小委員会 : 標準注意 検査法 (CAT) と標準意欲評価法 $(\mathrm{CAS})$ の開発とその 経過. 高次脳機能研究, 26:310-319, 2006.

20) Kring, A. M., Smith, D. A. \& Neale, J. M. : Individual differences in dispositional expressiveness ; development and validation of the Emotional Expressivity Scale. Journal of Personality and Social Psychology, 66 : 934949, 1994.

21) Kring, A. M. \& Earnst, K. S. : Nonverbal behavior in schizophrenia. In : Nonverbal behavior in clinical settings (eds Philippot, P., Feldman, R. S. \& Coats, E. J.). Oxford University Press, New York, 2003, pp. 263-286.

22) Kring, A. M. \& Sloan, D. M. : The Facial Expression Coding System (FACES) ; Development, validation, and utility. Psychological Assessment, 19 : 210-224, 2007.

23) Mammucari, A., Caltagirone, C., Ekman, P., et al. : Spontaneous facial expression of emotions in brain-damaged patients. Cortex, $24: 521-533,1988$.

24) Mandal, M. K., Asthana, H. S., Mandan, S. K., et al. : Hemifacial display of emotion in the resting state. Behavioural Neurology, 5 : 169-171, 1992.

25) Nomura, M. \& Yoshikawa, S. : Gaze and facial expressions when talking about emotional episodes. Psychologia, $54: 15-26,2011$. 


\title{
Comparative Study of Emotional Expressions of Patients with Left Versus Right Hemisphere Damage - Relationships between Facial Expressions and Rating Scales of Motivation and Psychiatric Symptoms-
}

\author{
Naoya Obama*,** Jun Tanemura***
}

We examined relationships between a quantitative analysis of facial expressions and the questionnaire or behavior rating scale of 38 patients with right hemisphere damage, 34 patients with left hemisphere damage, and 12 patients with bilateral hemisphere damage. The Facial Expression Coding System (FACES) was used to evaluate facial expressions and the Japanese version of the Apathy Evaluation Scale Informant version (AES-I-J), Clinical Assessment for Spontaneity (CAS), and Neuropsychiatric Inventory (NPI) were used for evaluate motivation and psychiatric symptoms. Patients with right hemisphere damage showed a significant loss of motivation compared with patients with other hemisphere damage. The expression on FACES were highly correlated with the motivation or psychiatric symptom scores of AES-I-J, CAS, and NPI, as seen in the following pairs : sadness (FACES) and depression (NPI), happiness (FACES) and euphoria (NPI), indifference (FACES) and total score (AES-I-J), indifference (FACES) and total score (CAS), indifference (FACES) and indifference (NPI). The expressions on FACES were highly correlated with rating scales of motivation and psychiatric symptoms. Consequently, FACES could be useful for evaluating emotional states after cerebral damage. Patients with right hemisphere damage showed high scores for surprise, happiness, and indifference. Patients with left hemisphere damage showed high scores for sadness only. The results suggest that patients with right hemisphere damage show positive emotional valence, whereas those with left hemisphere damage show negative emotional valence on FACES.

\footnotetext{
* Department of Rehabilitation, Kurashiki Kinen Hospital. 831 Nakashima, Kurashiki-shi, Okayama 710-0803, Japan

** Doctoral Program in Sensory Science, Graduate School of Health Science and Technology, Kawasaki University of Medical Welfare

*** Department of Sensory Science, Faculty of Health Science and Technology, Kawasaki University of Medical Welfare
} 